Ю.С. Сулаберидзе

Восприятие Кавказа декабристами: культурный тип декабриста на Кавказе

doi:10.31518/2618-9100-2020-6-3

УДК 930.85, 94(47).073, 94(479.22)

Выходные данные для цитирования:

Сулаберидзе Ю.С. Восприятие Кавказа декабристами: культурный тип декабриста на Кавказе // Исторический курьер. 2020. № 6 (14). С. 53-71. URL: http://istkurier.ru/data/2020/ISTKURIER-20206-03.pdf
Yu.S. Sulaberidze ${ }^{*}$

\section{The Perception of the Caucasus by the Decembrists: Decembrist Cultural Type in the Caucasus}

doi:10.31518/2618-9100-2020-6-3

How to cite:

Sulaberidze Yu.S. The Perception of the Caucasus by the Decembrists: Decembrist Cultural Type in the Caucasus // Historical Courier, 2020, No. 6 (14), pp. 53-71. [Available online:] http://istkurier.ru/ data/2020/ISTKURIER-2020-6-03.pdf

Abstract. The author of the article analyzed the problem of the perception of the Caucasus, its nature, landscape, history, culture, mentality, customs and traditions. A certain cultural type of decembrists is distinguished by their tolerance towards ethnic groups of the Caucasus, understanding of the features of their lifestyle. The behavioral model of the Decembrists, who were active participants in hostilities in the Caucasus, is characterized. In connection with the comparative characteristics of the behavior of the Decembrists and the highlanders, the attitude of the Decembrists to the Caucasus is analyzed, revealing the inner nature of the Decembrists itself, as a Russian phenomenon. This discourse reveals an opportunity to identify the "cultural core" of Decembrism, to look at it from the side of "another culture", at the junction of the interaction of various cultures and civilizations. The article reveals the perception of the Caucasus by the decembrists E.E. Lachinov, A.S. Gangeblov, A.E. Rosen, N.I. Laurer, A.P. Belyaev, whom the author refers to as the "cultural type of the Decembrists". By fate, they were in the Caucasus at the center of the most important events of the 1820-1840-s. The Caucasus war made adjustments to the worldview of the decembrists about the "civilized mission" of the impire in the Caucasus, changed their attitude towards the Caucasian cultural world, and revealed its self-sufficiency. Caucasus, as a special socio-cultural phenomenon, made a strong impact on the progressive representatives of Russian society, opened for them a new field of activity aimed at the development of Russia.

Keywords: the Decembrists; Caucasus; E.E. Lachinov; A.S. Gangeblov; A.E. Rosen; A.P. Belyaev.

The article has been received by the editor on 16.03.2020.

Full text of the article in Russian and references in English are available below.

Аннотация. Автор статьи анализирует проблему восприятия декабристами Кавказа, его природы, ландшафта, истории, культуры, особенностей менталитета, обычаев и традиций. Выделяется определенный «культурный тип декабриста», отличающийся толерантностью в отношении этносов Кавказа, пониманием особенностей их образа жизни, стремлением усвоить лучшие традиции кавказской культуры. Также выявлен культурно-исторический тип «декабриста-кавказоведа», определены особенности его ментальности, культурноисторического поведения. Характеризуется поведенческая модель декабристов, бывших активными участниками боевых действий на Кавказе. В связи со сравнительной характеристикой поведения декабристов и горцев проанализировано отношение декабристов к Кавказу, при этом выявлена внутренняя природа самого декабризма как российского

\footnotetext{
* Сулаберидзе Юрий Семенович, кандидат исторических наук, Институт кавказоведения Тбилисского государственного университета им. Ив. Джавахишвили, Тбилиси, Грузия, e-mail: iuri.sulaberidze@mail.ru Sulaberidze Yuri S., PhD, Caucasus Institute of the Jvane Javakhishvili Tbilisi State University, Tbilisi, Georgia, email: iuri.sulaberidze@mail.ru
} 
феномена. В данном дискурсе обнаружена возможность выявить «культурное ядро» декабризма, посмотреть на него со стороны «иной культуры», на стыке взаимодействия различных культур, цивилизаций. В статье раскрывается восприятие Кавказа декабристами Е.Е. Лачиновым, А.Е. Гангебловым, А.Е. Розеном, Н.И. Лорером, А.П. Беляевым, которые, по мнению автора, относятся к «культурному типу декабристов». Волею судьбы они оказались на Кавказе в центре важнейших событий 1820-1840-х гг. Кавказская война внесла коррективы в мировоззрение декабристов о цивилизаторской миссии империи, изменила их отношение к кавказскому культурному миру, раскрыла его самодостаточность. Кавказ как особый социокультурный феномен произвел сильное воздействие на прогрессивную часть русского общества, открыл для них новое поле деятельности, нацеленной на поступательное развитие России.

Ключевые слова: декабристы; Кавказ; Е.Е. Лачинов; А.Е. Гангеблов; А.Е. Розен; Н.И. Лорер; А.П. Беляев.

Проблема декабризма продолжает оставаться одной из самых актуальных в исторической науке, т.к. это явление оказало большое влияние на последующее развитие России ${ }^{1}$. Не вдаваясь в историографическую дискуссию о характере декабризма как общественного движения, его идеологии, структуре организации, хотелось бы отметить перспективность исследования декабризма в рамках культурной антропологии, рассмотрения декабристского движения как комбинации различных социокультурных типов, отражающих спектр оппозиционности по отношению к власти со своим набором культурных ценностей ${ }^{2}$.

Российская жизнь после Отечественной войны 1812 г. и заграничных походов стала более многообразной, сложной и противоречивой так же, как и типология культурных героев. Разнообразие интересов, ценностей подрывали основы традиционной морали, радикализировали общественные настроения. Декабризм как общественное явление отражал кризис прежних общественных и ментальных структур общества. Общение с «чужим, иным» миром ценностей раскрыло природу "русского восприятия», обнаружило его сущность, специфику. Феномен «декабристы на Кавказе» как научный дискурс представляет особый интерес для обнаружения природы декабризма, открытия тех его аспектов проявления, которые оставались до сих пор в тени исследования.

Ю.М. Лотман с позиций семиотики раскрыл особенности восприятия декабризма как культурно-общественного явления. В его семиотической картине декабристы предстают в повседневной жизни, на службе, в тайных организациях. В своих работах Ю.М. Лотман впервые обратил внимание не на идеологию, политические доктрины декабризма, а на поведенческие модели, рассматривая образ действий декабристов как выражение сложных этических, религиозных, эстетических, бытовых и других семиотических норм ${ }^{3}$. Прежде всего, декабристы были активными деятельными личностями. Творческая энергия создавала особый тип русского человека, ориентированного на преобразование самого себя и окружающей среды. Появление и развитие нового культурного типа Ю.М. Лотман связывал с асимметричностью диалога, где рождение новой культурной парадигмы происходит на «периферии» (границе) в процессе диалога культур. Была отмечена «диалогичность» поведения декабристов: сознанию декабриста была свойственна резкая поляризация моральных и политических оценок, т.к. любое поведение оценивалось в поле «хамства», «подлости», «тиранства» и «либеральности», «правдивости», «героизма». Выделяя основные качества

\footnotetext{
${ }^{1}$ См., напр.: Андреева Т.В. Тайные общества в России в первой трети XIX в: правительственная политика и общественное мнение. СПб., 2009; Орлик О.В. Декабристы и внешняя политика России. М., 1986; Киянская О.И. Декабристы. М., 2015; Эрлих С.Е. Война мифов: память о декабристах на рубеже тысячелетий. СПб., 2016.

${ }^{2}$ Балахнина В.Ю. Декабристы как социокультурный тип человека. Саарбрюккен, 2011.

${ }^{3}$ Лотман Ю.М. Беседы о русской культуре. Быт и нравы русского дворянства (XVIII - начало XIX века). СПб., 2001. C. 332.
} 
поведения, Ю.М. Лотман подчеркивал присущий им «героизм»: «Весь облик декабриста был неотделим от чувства собственного достоинства. Он базировался на исключительно развитом чувстве чести. В своих поступках они видели высокий смысл». Декабризм был частью высокой дворянской культуры, в которой знаковые элементы некой театральности, картинности соседствовали с простотой и искренностью, что нарушало иерархичность господствующей культуры. Поэтому декабристы не испытывали чувства неполноценности, которое было свойственно последующим представителям русской интеллигенции ${ }^{4}$.

Кавказовед Ю.Ю. Карпов в своей содержательной работе «Взгляд на горцев. Взгляд с гор» представил феномен восприятия «чужой культуры». Он выявил характерные черты маскулинной культуры горцев, их восприятие природы, общества. Горцы жили под жестким регламентом общинного быта, семейно-родственных связей, соблюдали адаты и этику чести и достоинства. Смысл их существования был предначертан - он был направлен на героические дела, активное противоборство, достижение своего совершенства. Ю.Ю. Карпов отметил и различия «героизма» русского человека и горца, связанные с природой «души». Русская душа широка, но она, подобно равнине, разбросана, и не всепоглощающая. Душа горца выходит из узких расщелин гор, она импульсивна, эмоциональна, но направлена на целесообразность своего движения. Поэтому ее действия могут быть изворотливы, гибки. Она стремится к совершенству, поэтому должна выглядеть, показать себя совершенной. Отсюда ее героизм, гостеприимство, аталычество, братство 5 .

Многое роднит декабристов и горцев - активность, проявление героизма, братство, смелость, но со своими особенностями и содержанием. Декабристы были высланы на Кавказ, чтобы принять участие в Кавказской войне, которая внесла коррективы в их мировоззрение, культурный тип поведения. Эти процессы еще в дореволюционной историографии были проанализированы В.А. Потто, а в новейшей историографии В.В. Лапиным. В.А. Потто отмечает особый дух «старых кавказцев». Характеризуя Отдельный Кавказский корпус, В.В. Лапин приводит ряд интересных соображений о поведении офицеров и солдат. Он отмечает, что Кавказская армия была особенной. В ней не ощущалась та дистанция между высшими и нижними чинами, которая присутствовала в других частях русской армии: «На Кавказе власти столкнулись с уникальным явлением - “приватизацией” войны, которая для солдат и офицеров стала не просто выполнением присяги, а личным делом, которое они выполняли не за страх, а за совесть». Историк Кавказской войны утверждает, что Кавказский Отдельный корпус «усвоил не только боевые приемы горцев, но и элементы туземной военной культуры - все это способствовало завершению войны <..> произошло сближение знаковых систем обеих сторон, которые стали лучше понимать друг друга» (выделено нами. - Ю. С.) ${ }^{6}$.

Знаковые системы отражают картину мира, ментальность «декабристов-кавказоведов» и горцев. Историк ментальности А.Я. Гуревич подчеркивал, что «поведение людей соответствует не столько объективным условиям их существования, сколько картине мира, навязываемой языками культуры, воспоминаниями, социальным общением» ${ }^{7}$. В исследовании С.П. Вольф показано, что в картине мира декабристов существовал мифологический образ Востока. И в то же время Кавказ, как ментальный конструкт, отожествлялся декабристами с пространством угрозы европейскому пониманию идеала. В этом заключалась амбивалентность восприятия Кавказа, «Русского Востока» в картине мира декабристов. К середине $\mathrm{XIX}$ в. под влиянием испытаний Сибирью и Кавказом в их представлениях произошла опре-

\footnotetext{
4 Лотман Ю.М. Декабрист в повседневной жизни // Литературное наследие декабристов. Л., 1975. С. 25-74.

${ }^{5}$ Карпов Ю.Ю. Взгляд на горцев. Взгляд с гор: мировоззренческие аспекты культуры и социальный опыт горцев Дагестана. СПб., 2007.

${ }^{6}$ Лапин В.В. История Кавказской войны. Пособие к лекционному курсу. СПб., 2003. С. 62.

${ }^{7}$ Гуревич А.Я. От истории ментальности к историческому синтезу // Споры о человеке. Дискуссии о настоящем и будущем исторической научной французской школы «Анналы». М., 1993. С. 26.
} 
деленная трансформация общественного идеала в системе европейского просвещения, полнее обозначились поиски национальной идентичности ${ }^{8}$.

Сближению знаковых систем «русских кавказцев» и туземцев, горцев предшествовала длительная, противоречивая история мирного сосуществования и военных действий. Как известно, среди правящей военной и чиновничьей элиты имперской администрации менялись подходы и пути для сближения позиций. Этот процесс нашел отражение в исследовании Я.А. Гордина «Кавказская Атлантида». Историк Кавказской войны отмечает, что имперская администрация предлагала свои пути разрешения проблемы на основе адаптации горского общества к российскому стилю образа жизни. Выступая против восточного деспотизма, она навязывала просвещенный абсолютизм европейского типа: «Военно-политический тупик был предопределен не только нежеланием и невозможностью для русской стороны воспринимать горский мир со всей его органикой, интенсивное разрушение которой привело к духовной катастрофе и уродливой мутации, но и невозможностью для горцев отказаться от составляющих этой органики, от набеговой системы. Поэтому компромисс и не был достигнут» ${ }^{9}$.

Все это непосредственно относится и к характеристике поведенческой модели декабристов, бывших активными участниками боевых действий на Кавказе. В связи со сравнительной характеристикой поведения декабристов и горцев представляется возможность проанализировать отношение декабристов к Кавказу, обнаруживая внутреннюю природу самого декабризма как российского феномена. В данном дискурсе обнаруживается возможность выявить «культурное ядро» декабризма, посмотреть на него со стороны «иной культуры», на стыке взаимодействия различных культур, цивилизаций. В статье рассматривается проблема восприятия декабристами истории и культуры Кавказа, перспектив его развития в составе Российской империи. Выявляются базовые культурно-идеологические установки «декабристов-кавказоведов», особенности их воззрений на миссию России в отношении народов Кавказа. В связи с этим проблема восприятия Кавказа рассматривается сквозь призму деятельности Е.Е. Лачинова, А.С. Гангеблова, А.Е. Розена, Н.И. Лорера, А.П. Беляева, оставивших потомкам свои воспоминания о Кавказе.

Декабризм своими корнями связан с русской почвой, но испытал влияние Запада. Его соприкосновение с кавказским миром внесло в ментальное ядро декабризма новые оттенки. Этой проблеме в контексте Кавказской войны посвящена лекция Я.А. Гордина ${ }^{10}$. М.И. Седова справедливо утверждает, что политическая культура декабристов выработала новое политическое сознание, ориентации, нормы, традиции, поведение в общении с другим миром $^{11}$. Это и предстоит выяснить через парадигму диалога цивилизаций.

Цель работы - выявление культурно-исторического типа «декабриста-кавказоведа», особенностей его ментальности, культурно-исторического поведения. Выявление восприятия декабристами Кавказа тесно связано с их политической культурой, раскрывающей их нравственно-психологический мир, отношение к свободе, чести и достоинству. Предстоит обнаружить «ментальное ядро» декабризма, дуализм его природы, отраженный в нравственном кодексе православия и идеологии Просвещения.

О декабризме на Кавказе существует довольно значительная историография. Мы затронем в основном местную, грузинскую историографию. В дореволюционной историографии одним из первых исследователей декабризма на Кавказе был Е.Г. Вейденбаум, чиновник, который долгое время жил и работал в Тифлисе. Е.Г. Вейденбаум, питомец Санкт-Петербургского университета, на долгие годы связал себя с Кавказом, который очень полюбил, оставил большое научное наследие. Его фонд в Национальном Центре рукописей

\footnotetext{
${ }^{8}$ Вольф С.П. Представления о пространстве и времени в картине мира декабристов: автореф. дис. ... канд. ист. наук. Омск, 2012. С. 18, 20.

${ }^{9}$ Гордин Я.А. Кавказская Атлантида. 300 лет войны // Мир книг [Электронный ресурс]. URL: https://mirknig.com/read 222249-1 (дата обращения: 22.12.2020).

${ }^{10}$ Гордин Я.А. Кавказская война (1722-1864) как диалог культур. СПб., 2018. 28 с.

${ }^{11}$ Седова М.И. Политическая культура декабристов в контексте российской истории ХІХ века: автореф. дис. ... д-ра ист. наук. Краснодар, 2006. С. 22.
} 
Грузии поражает обилием кавказоведческих материалов и представляет большую ценность для науки. Среди них черновые материалы о декабристах на Кавказе, которые отчасти были опубликованы в журнале «Русская старина» и газете «Кавказ» ${ }^{12}$. О декабристах на Кавказе писали М.А. Полиевктов ${ }^{13}$, С.С. Эсадзе $\mathrm{e}^{14}$.

Необходимо также выделить работы М.О. Косвена, В.А. Парсамяна, М.Г. Нерсисяна, Г.А. Дзидзарии, Х.М. Ибрагимбейли, О.В. Орлик ${ }^{15}$. Ценность этих работ состоит в том, что в них подробно анализируется деятельность декабристов на Кавказе по изучению истории, быта Грузии, Армении, Азербайджана. В грузинской советской историографии декабристам на Кавказе посвящены работы Л. Барамии, О. Гвинчидзе, Г. Гозалишвили, М. Гоцадзе, А. Маградзе, Дж. Ватейшвили, Г. Хачапуридзе. Отдельные части исследования Г.В. Хачапуридзе «К истории Грузии первой половины XIX века» (1950) посвящены дворянскому движению против царизма в России, возникновению, идеологии и планам тайного общества ${ }^{16}$.

Наибольший вклад в изучение декабризма в Грузии внесли литературовед В.С. Шадури и историк Б.К. Сохвадзе. В.С. Шадури написал объемное исследование «Декабристская литература и грузинская общественность» (1958), которое не потеряло своего научного значения по наше время. Вторая его работа о В.Д. Вольховском «Покровитель сосланных на Кавказ декабристов и опальных литераторов» (1979) также ценна фактическим материалом ${ }^{17}$. В историографии декабризма на Кавказе особое место занимает книга Б.К. Сохвадзе «Декабристское движение и грузинская общественность» ${ }^{18}$. Автор подробно анализирует историографию темы, отмечает недостатки дореволюционной историографии, упоминая о трудах Е.Г. Вейденбаума и обвиняя его в тенденциозности. Говоря об источниках, Б.К. Сохвадзе подчеркнул значение воспоминаний грузина-декабриста А. Гангеблова (Гангеблидзе), а также А. Розена, А. Торнау, особо отметил значение публикации близкого друга декабристов А. Чавчавадзе «Краткий исторический очерк Грузии с 1801 по 1831 г.» в «Кавказском Сборнике» за 1902 г. (т. 23). Одним из центральных вопросов работы Б.К. Сохвадзе было доказательство существования в Отдельном Кавказском корпусе тайного общества декабристов. Автор, опираясь также на выводы работы Р.Д. Сакварелидзе, утверждал, что оно действительно было ${ }^{19}$.

\footnotetext{
${ }^{12}$ Вейденбаум Е.Г. Декабристы на Кавказе в 1829 году // Русская старина. 1903. Т. 34. С. 481-502; Вейденбаум Е.Г. Александр Бестужев на Кавказе // Кавказ. 1898. № 29.

${ }^{13}$ Полиевктов М.А. Записки декабриста А.М. Муравьева в библиотеке Тбилисского университета // Труды Тифлисского государственного университета. 1936. Т. 1. С. 348-354.

14 Эсадзе С.С. Декабристы в Закавказье. Тбилиси, 1925.

${ }^{15}$ Косвен М.О. Декабристы-кавказоведы // Косвен М.О. Этнография и история Кавказа: иссл. и мат-лы. М., 1961. С. 155-184; Парсамян В.А. Декабристы в Армении. Ереван, 1975. С. 81-95; Декабристы об Армении и Закавказье: сб. док-тов и мат-лов / сост. и ред. М.Г. Нерсисян. Ереван, 1985. Ч. 1; Дзидзария Г.А. Декабристы в Абхазии. Сухуми, 1970; Ибрагимбейли Х.М. Россия и Азербайджан в первой трети ХIX века: (из военнополитической истории). М., 1969; Орлик О.В. Декабристы и внешняя политика России. М., 1984. С. $215-182$.

${ }^{16}$ Барамия Л. Декабрист А. Гангеблов (Гангеблидзе). Тбилиси, 1951; Барамия Л. Декабристы в Грузии. Тбилиси, 1955; Гвинчидзе О.Ш. Из истории общественного движения в России конца XVIII в. (Евграф и Петр Грузиновы): автореф. дис. ... канд. ист. наук. Тбилиси, 1958; Гозалишвили Г.К. Заговор 1832 года. Тбилиси, 1970. Т. 2; Гоцадзе М.К. Соломон Додашвили. Тбилиси, 1955; Маградзе А. Декабристское восстание 1825 г. // Заря Востока. 1940. № 999. 26 дек.; Ватейшвили Дж.Л. Декабристы на Кавказе. Дело Сухорукова // Вопросы новой истории Грузии. Тбилиси, 1971. С. 223-258; Хачапуридзе Г.В. Дворянское движение в Грузии в 30-х годах XIX столетия // Вопросы истории. 1950. № 7. С. 45-60; Хачапуридзе Г.В. К истории Грузии первой половины XIX века. Тбилиси, 1950. С. 273-420.

${ }^{17}$ Шадури В.С. Декабристская литература и грузинская общественность. Тбилиси, 1958; Шадури В.С. Покровитель сосланных на Кавказ декабристов и опальных литераторов: неизвестные материалы о лицейском друге Пушкина В.Д. Вольховском. Тбилиси, 1979.

${ }^{18}$ Сохвадзе Б.К. Декабристское движение и грузинская общественность. Тбилиси, 1976.

${ }^{19}$ Сакварелидзе Р.Д. К вопросу о существовании «Кавказского тайного общества» // История СССР. 1959. № 5. C. $126-127$.
} 
В современной грузинской историографии опубликован ряд интересных работ. Это, прежде всего, исследование проф. О.К. Жордании о декабристе А.М. Муравьеве, работы Д.Г. Канделаки, Ю.С. Сулаберидзе ${ }^{20}$.

Не затрагивая российской историографии, укажем на несколько работ, имеющих отношение к проблеме восприятия Кавказа декабристами. Это труды Д.С. и С.Л. Дударевых, Е.В. Мирзоян, М.И. Серовой ${ }^{21}$. В них рассматривается деятельность декабристов А.А. БестужеваМарлинского, А.И. Одоевского, А.П. Беляева, Е.Е. Лачинова, Н.И. Лорера и др.

Приступая к исследованию проблемы, отметим, что ограничимся характеристикой восприятия Кавказа несколькими декабристами, условно определенными в категорию «культурный тип декабриста». Это связано с особенностями мировосприятия, процессом освоения «другой культуры».

Особый интерес для раскрытия культурного облика декабристов на Кавказе представляет фигура Евдокима Емельяновича Лачинова (1799-1875). Е.Е. Лачинов происходил из дворян Воронежской губернии. На военной службе с августа 1816 г. В 1816-1817 гг. принял участие в посольстве А.П. Ермолова в Персию. По возвращении в 1818 г. поступил в Московское учебное заведение для колонновожатых. Прошел школу Н.Н. Муравьева, стал военным топографом. С сентября 1820 г. состоял исправляющим должность старшего адютанта по Генеральному штабу при Главной квартире 2 армии на Украине. С 1825 г. был участником Южного общества декабристов, в 1826 г. осужден за участие в декабристском движении, разжалован и сослан на Кавказ. В январе 1827 г. прибыл в Тифлис для службы в 39-й егерский полк 20-й пехотной дивизии. Е.Е. Лачинов принимал активное участие в русско-персидской войне 1826-1828 гг. и русско-турецкой войне 1828-1829 гг., походе 1832 г. в Чечню. Как талантливый летописец военных баталий, оставил свои воспоминания в «Автобиографии», «Записках декабриста», «Записках русского солдата», часть из них была опубликована в «Кавказском Сборнике», но значительная часть оставалась в архиве ${ }^{22}$.

Как подчеркивает исследователь истории декабризма на Кавказе М.Г. Нерсисян, Е.Е. Лачинов оставил блестящие описания этнографии, археологии Армении, проявил большие познания военного топографа в работе «Статистическое описание Эриванской области», выполненной по распоряжению генерала А.И. Красовского. Она сопоставима с исследованием И. Шопена «Исторический памятник состояния Армянской области в эпоху ее присоединения к Российской империи», изданным в 1852 г. в Санкт-Петербурге. Декабрист изучил историю Армении, опираясь на сочинения армянского ученого-мхитариста М. Чамчяна. Е.Е. Лачинов достойно выполнил задание генерала Красовского, героя освобождения Армении ${ }^{23}$.

Особую ценность для исследователя Кавказа представляет рукопись декабриста «Моя исповедь». Значение этой работы заключается в том, что в ней отражены сокровенные мысли декабриста, выраженные через особый стиль автора. Он умел сравнивать, находить поднаготную исторических явлений, обнаруживать их смысл. Е.Е. Лачинов отмечал многообразие оттенков в декабристском движении. В своем большинстве, по его мнению,

\footnotetext{
${ }^{20}$ Жордания О.К. Декабрист А.М. Муравьев и его записки «Мой журнал». Тбилиси, 1990; Канделаки Д.Г. Дневниковые записки декабриста Е.Е. Лачинова // Русский язык и литература в пространстве мировой культуры: мат-лы XIII Конгресса МАПРЯЛ. СПб., 2015. С. 247-251; Сулаберидзе Ю.С. Декабрист Е.Е. Лачинов: размышление о прожитом. Саарбрюккен, 2016.

${ }^{21}$ Дударев Д.С., Дударев С.Л. Жизнь северокавказских горцев в мемуарах декабристов // Вопросы истории. 2015. № 1. С. 79-89; Мирзоян Е.В. Сибирская и кавказская ссылки декабристов в 1825-1856 гг.: Опыт сравнительного исследования: автореф. дис. ... канд. ист. наук. Новосибирск, 2003; Серова М.И. Влияние декабристов на развитие культуры Черномории // Культурная жизнь юга России. 2014. № 1 (52). С. 89-92.

${ }^{22}$ Национальный центр рукописей Грузии (НЦРГ). Ф. ROS. Оп. 1. Д. 372.; Ф. Е. Вейденбаума. Д. $1379,1397$. Архивные материалы опубликованы, см.: Сулаберидзе Ю.С. Декабрист Е.Е. Лачинов: размышления о прожитом. Саарбрюккен, 2016.

${ }^{23}$ Нерсисян М.Г. Декабрист Е. Лачинов и его записки об Армении // Из истории русско-армянских отношений. Ереван, 1956. Кн. 1. С. 179-220.
} 
декабристы были «люди мыслящие», которые не только мечтали о преобразовании России на европейский лад, но и пытались преодолеть «замедленность развития» ${ }^{24}$.

Современные исследователи декабризма отмечают, что «бешеный исторический поток безжалостно столкнул между собой людей с принципиально разными уровнями политического сознания» ${ }^{25}$. Сознание Е.Е. Лачинова было активно-деятельное, в нем преобладали не разрушительные действия, а созидательные, направленные на преобразование общества, а также морального облика личности. В таком контексте воспринималась «иная культура», кавказская культура, цивилизация, столь разная, казавшаяся на первый взгляд "дикой» ${ }^{26}$. Текст «Исповеди» насыщен преклонением перед вершинами Кавказа, уважением к гордым людям, которые несут особую ментальность, отличную от степей, равнин Центральной России, откуда он был сам родом: «Чем ближе подходил я к горам, тем окрестности становились приятнее. Чем больше я приближался к Грузии, тем сильнее укреплялась мысль, что не возвратиться мне на родину <...> Не берусь выразить разнообразие прелестей горной природы. Здесь сквозь утесы гранита прокрались деревья и висят над бездною; различные положения их представляют нечто похожее на театральные декорации». Внимательный взгляд декабриста отмечает, что «обиталища грузин гнездятся на таких высотах, что заставляет изумляться, куда необходимость может занести человека» ${ }^{27}$.

При чтении «Моей Исповеди» Е.Е. Лачинова понимаешь, что смысл многого скрывается между строк. Одной из особенностей мировосприятия Е.Е. Лачинова является тонкость ума, образность мышления. Это видно при описании «иной» культуры, традиций, общение с которыми открывало новый облик и самой России, ее воинства, пришедшего освобождать Кавказ. «Картины жизни Тифлиса чуждые для европейца - это живое разнообразие», - отмечает внимательный наблюдатель. Для Кавказа открывается возможность обновления на стыке двух миров. Автор «Исповеди» надеется на возрождение Тифлиса на новой основе, и тем самым открывает сокровенную черту ментальности грузин - стремление к возрождению «золотого века»: «Буду ли я любоваться тобою, с душою, обновленного возрождением надежд на будущее благополучие?» ${ }^{28}$.

Вернувшись в Тифлис в 1827 г., через девять лет после первого посещения, Е.Е. Лачинов поражен теми изменениями, которые произошли в нем. Центр города стал европейским, он причудливо соседствует с азиатскими чертами города, разнообразным, сочным колоритом старого Тифлиса. Вот краткое описание влияния европейской культуры на культуру азиатскокавказскую: «Более девяти лет не был я в Тифлисе и нашел множество перемен: улица больших зданий, хорошей архитектуры, выстроена там, где прежде стоял только дом главнокомандующего, большой, но не красивый, и по площади были разбросаны несколько землянок. Казармы, гошпиталь и другие строения украшают город, представляющий в самом безобразии своем нечто любопытное для взора, непривычного к безвкусию азиатов новейших времен. На базаре можно найти предметы утонченной роскоши запада и великолепия восточного, и там же, в лавках, работают хлебники, харчевники, слесари, кузнецы, портные, сапожники и всякие мастеровые; словом, везде царствует смешение следов образованности с признаками невежества, и смешение это придает какую-то оригинальность, которую, по моему мнению, нельзя назвать совершенно неуместною» (выделено нами. - Ю. С. $)^{29}$.

О чем говорит заключение Е.Е. Лачинова? Это подтверждение «отсталости Русского Востока» в духе официальной великодержавной концепции цивилизаторской миссии империи или стремление показать процесс диалога культур? Исходя из текста, можно утверждать, что его мысль была обращена на понимание иной культуры. Это не только метафорическое описание красот Кавказа, но ощущение, что здесь, в Азии, зарождалась колыбель

\footnotetext{
${ }^{24}$ Декабристы об Армении и Закавказье... С. 40.

${ }^{25}$ Гордин Я.А. Мятеж реформаторов. 14 декабря 1825 г. Л., 1985. С. 181.

${ }^{26}$ См.: Багратион-Мухранели И.Л. Другая жизнь и берег дальний. М., 2014.

${ }^{27}$ Сулаберидзе Ю.С. Декабрист Е.Е. Лачинов: размышления о прожитом... С. 74-75.

${ }^{28}$ Там же.

${ }^{29}$ Декабристы об Армении и Закавказье... С. 46.
} 
европейской культуры. Завоевывая Кавказ, русские воины в лице декабристов усваивали его культуру, как материальную, так и духовную. Необходимо отметить, что декабристов привлекало в горцах многое такое, что почиталось и ими самими. Это следование особому горскому этикету («адыге хабзе»), где уважалась свобода, почитались мужество, честь и достоинство воина, что было близко и понятно передовому сознанию декабристов. Волею судьбы оказавшиеся в горах Кавказа, они встретили достойных соперников, защищавших свою землю, семьи, традиции и обычаи. Как люди чести, воинского долга, любви к Родине, «декабристы-кавказоведы» не могли не оценить нравственные принципы горцев.

Как справедливо отмечают исследователи горского этикета Ю.Ю. Карпов, В.В. Лапин, Я.А. Гордин, культура горцев оказала влияние на культуру поведения декабристов. Это находило отражение в повседневности: употреблении кавказской пищи, ношении черкесок, правилах общения. Кавказ такой же разнообразный и в то же самое время единый, как и само движение декабризма. Поражает глубокое познание географии и топографии Грузии Е.Е. Лачинова, не случайно у него просили совета видные военачальники - сказывалось обучение в школе колонновожатых Н.Н. Муравьева. Е.Е. Лачинов подмечает основную ментальную черту Грузии - ее многообразие, партикуляризм, что представляет одновременно как позитив, так и негатив. Он пишет: «Грузия пересекается в различных направлениях высокими хребтами гор, которые затрудняют до чрезвычайности внутреннее сообщение, производят и то различие климатов, непостоянства, которых столь справедливо опасаются» (выделено нами. - Ю.С.) ${ }^{30}$.

Подразумевал ли здесь декабрист политическое непостоянство, феодальную раздробленность Грузии, сопровождаемую раздорами и внешней агрессией? Об этом сложно сказать, но из текста «Моей исповеди» следует, что Е.Е. Лачинов был знаком с историей Грузии. Трудно отказать автору записок в глубине философского размышления над вопросами восприятия сложного и противоречивого мира Кавказа, в поисках компромисса различного типа культур, поведенческих моделей. В нем много хаотического, неподвластного, для покорения которого русская власть использовала как мирные, так и военные средства ${ }^{31}$. Так, Е.Е. Лачинов описывает область Джаро-Белаканы, завоеванную с большим трудом: «Более ста лет назад часть лезгин вышла из Дагестана и, покорив Грузию, живших по левую сторону реки Алазани, сделала их своими данниками. Цари грузинские не в силах были вытеснить их из своих владений и с тех пор победители основали жилища свои в ущельях у подошвы черных гор, составляющих отрасль Кавказского хребта. Власть не утвердилась временем; покоренные оставили Христианскую веру, не сделавшись поклонниками Магомета, сохранили некоторые обряды христианства, не забыли языка предков и грузинское наречие удержалось в общем между им употребляемыми. Властелины же их, и отдалившись от соотечественников, не изменили характера своего: хищничество и жестокость этих неразлучных спутников дикости составляют и любимое упражнение, и забаву их. Они не пропускают случаев к грабительству, несмотря на опасное для них соседство русских; примеры строгости над виновными не могли еще укротить совершенно буйство их» ${ }^{32}$.

В наблюдениях автора «Записок русского солдата» чувствуется прекрасное знание этнографии «освобождаемой окраины» - Армении. Участие декабристов в освобождении Армении отражено в армянской историографии (М.Г. Нерсисян, В.А. Парсямян). В частности, сообщается о героизме декабристов при освобождении Карса ${ }^{33}$. Е.Е. Лачинов описывает освобождение святыни армян Эчмиадзина: «Генерал Красовский с трехтысячным отрядом 17 августа 1827 года при селе Ушагане разбил 30-тысячное скопище персиян, и тем самым избавил от гибели Эчмиадзинский монастырь» ${ }^{34}$.

\footnotetext{
${ }^{30}$ Сулаберидзе Ю.С. Декабрист Е.Е. Лачинов: размышления о прожитом... С. 77-78.

${ }^{31}$ Декабристы об Армении и Закавказье... С. 53. О мировосприятии грузин, армян, азербайджанцев см.: Гачев Г.Д. Национальные образы мира. Кавказ. М., 2002.

${ }^{32}$ Сулаберидзе Ю.С. Декабрист Е.Е. Лачинов: размышления о прожитом... С. 77-78.

33 Парсамян В.А. Декабристы в Армении... С. 81-95.

${ }^{34}$ Лачинов Е.Е. Отрывок из «Исповеди» // Кавказский Сборник. 1876. Т. 1. С.123-196.
} 
Е.Е. Лачинов прекрасный летописец не только военных баталий, но и бытовых сцен местного населения, главным образом армян, т.к. бои в основном шли на территории Карса, Эривани, Арзрума, которые освобождал и его 39-й егерский полк. Он образно описывает армянские поселения, отмечая их особенности: «Селение Алибат, в котором кочую я теперь, довольно велико и расположено на большой площади, окруженной большим лесом. Жилища стоят в шелковичных садах, выездами из деревни разбитых на кварталы; повсюду находятся во множестве ветвистые чинары, персики, грецкие орехи, гранаты, винные ягоды и другие плодовитые деревья; дикий виноград вьется вокруг огромных деревьев, переплетает ветви их, опускается к земле, вновь поднимается и, сплетением этим обрисовывая различные фигуры, цепляется за самые вершины: толщина его основания имеет иногда до пол-аршина в поперечнике. Лес уже одевается: прелестно-розовый цвет персиков, сливаясь с лилейною белизною и яркою зеленью, представляет восхитительный ландшафт; шелковица и другие деревья начинают только пускать отпрыски и обещают продолжительное наслаждение любителям природы, словом, места во всех отношениях превосходные: нельзя не жалеть, что прелестная страна эта досталась в удел людям, не умеющим пользоваться богатствами, вкруг них рассыпанными» ${ }^{35}$. Сцены, картины, рисуемые образным языком, законченные, и, несмотря на трагизм происходящего, вселяют надежду на избавление от турецкого ига, оздоровление жизни.

Таков сам автор: «Что скажу о себе? Я терпеливо переношу невыгоды своего положения, и надежда еще не оставляет меня. Думаю, что всего сильнее в человеке - надежда; чувство, понятия, способности, склонность часто изменяют ему; надежда едва ли когда оставляет его совершенно» (выделено нами. - Ю.С.) ${ }^{36}$. Е.Е. Лачинов верит в природу «русского духа», и это придает ему силу в самые тяжелые минуты испытаний. Он чувствует, что является участником великих дел освобождения. И свой героизм он видит в этом, оставаясь верным «духу свободы». Это не удалось совершить в самой России, но русские солдаты освобождают «Русский Восток», несут новую нравственность, европейскую культуру, которая привела к созданию тайных обществ в России, и это придает им «силу правды», которая сильнее «невежества, грубой силы». Такой смысл героизма: «Вот плоды кротости и справедливости; не ясно ли доказывается этим, что победа их несравненно быстрее и прочнее побед оружия» (выделено нами. - Ю.С.) ${ }^{37}$. Декабристские идеи не исчезли, они воплотились в Азии, на Кавказе, их принесли те, кто жертвует собой в том числе и ради будущего России. Свое кредо декабрист Е.Е. Лачинов выразил очень просто и лаконично: «Ты требуешь советов - не советы других спасут тебя, а собственно твоя твердость и деятельность» (курсив наш. - Ю. С.) $)^{38}$.

В этом суть понимания декабризма Е.Е. Лачинова - подвижничество, делание добра и борьба со «злом бесполезным». Этими же качествами отличался А.С. Гангеблов.

Александр Семенович Гангеблов (1801-1891) происходил из обрусевших грузин. Его предки выехали в Россию со свитой картлийского царя Вахтанга VI в 1724 г. Отец был военным, имел поместье на Южной Украине, мать - сербка из знатного рода Хорст. А.С. Гангеблов окончил Пажеский корпус. Поручик Измайловского полка А.С. Гангеблов был принят в Северное общество в апреле или мае 1825 г., в восстании 14 декабря участия не принимал, т.к. находился в то время в Петергофе. За участие в тайном обществе был арестован, впоследствии послан на Кавказ. Участвовал в войнах с Персией (1826-1828 гг.) и Турцией (1828-1829 гг.). Написал свои воспоминания уже после того, как вышел в отставку и поселился в родовом поместье в Екатеринославской губернии.

В «Воспоминаниях» А.С. Гангеблов оставил описания боев за Карс, Ахалцых, Арзрум, где проявил себя геройски, неоднократно упоминает тех декабристов, которые служили рядом с ним, - Н.Н. Депрерадовича, Д.А. Искрицкого, Н.Н. Оржицкого, З.Г. Чернышева,

\footnotetext{
${ }^{35}$ Сулаберидзе Ю.С. Е.Е. Лачинов: размышления о прожитом... С. 78.

${ }^{36}$ Декабристы об Армении и Закавказье... С. 59.

${ }^{37}$ Там же. С. 162.

${ }^{38}$ Там же. С. 181.
} 
А.А. Бестужева, В.Г. Голицына. Он отмечает, что «все декабристы в обе войны, как в персидскую, так и турецкую, служили одинаково ревностно и были награждаемы». Они сохраняли «дух» декабризма, не изменяли своим убеждениям: «В настроениях духа декабристов нисколько не замечалось, чтобы они приуныли, чтобы выражали сомнение в том, что жизненные надежды каждого из них им изменили» ${ }^{39}$.

Перед лицом Следственной комиссии А.С. Гангеблов показывал, что «всегда предпочитал медленные и постепенные меры решительным переворотам политическим» ${ }^{40}$. Это стало особенно значимым на Кавказе, где А.С. Гангеблов столкнулся с многообразием конфессий, укладов жизни, ментальностью его обитателей. «Русский Восток» поднял такие вопросы политического, нравственного характера, которые не могли быть решаемы только «политическими переворотами», а требовали нестандартных подходов. Об этом говорят воспоминания А.С. Гангеблова о Персии, Южном Азербайджане, в которых он отмечает, что местное население (азербайджанцы) очень хорошо относилось к русским, им нравилась русская музыка. Автор воспоминаний оставил довольно красочное этнографическое описание обычаев и традиций. Следует отметить, что А.С. Гангеблов так же, как и Е.Е. Лачинов, с уважением воспринимал культуру народов, живших на Кавказе, не принимал циничного и высокомерного отношения к их укладу жизни.

K «культурному типу декабриста» принадлежал Андрей Евгеньевич Розен (18001887) - поручик л.-гв. Финляндского полка, член Северного общества. Он принимал участие в подготовке восстания на Сенатской площади. Осужден на 10 лет каторги, которую отбывал в Чите и Петровском заводе, потом на поселении в Кургане. В 1837 г. отправлен на Кавказ, принимал участие в войне с горцами. В 1839 г. уволен со службы. С разрешения властей вернулся в Россию, умер в Изюмском уезде Харьковской губернии.

А.Е. Розен оставил колоритные записки военной службы на Кавказе, которые дополняют и расширяют представления о «культурном типе декабриста». В главе XII «От Кургана до Тифлиса» дано описание войска Донского, образа жизни казаков: «Донское войско есть единственное в своем роде: содержание его ничего не стоило правительству; с верой и правдою служило оно России в годину бедствий, - оставьте ему его особенность, его привычки, и одежду, и бороду, не мешать ему плавать на Дону с хлебом и вином; пускай он машет там веслом в мирное время для обогащения края, как машет он бесстрашно в военное время своею нагайкою и саблею для защиты государства» ${ }^{41}$. А.Е. Розен - за сохранение этнопсихологических особенностей казаков, за многообразие России, Кавказа, который поразил его своим величием гор, красотою природы, мужественным характером его жителей.

Кавказ обостряет все чувства человека, очищает и возвышает его душу: «При таких величественных видах, как на Кавказе, душа теснится, умиляется, смиряется и вместе с тем, сознавая свое назначение, возносится гораздо выше Кавказа, до небес...» ${ }^{42}$ А.Е. Розен оставил описание прекрасных картин Кавказа, Койшаурской долины Грузии, раскрывающих этнопсихологию горцев: «Север был отгорожен исполинскими ширмами или перегородкою. Солнце осветило наш вчерашний последний спуск и показало нам новую картину за горой, еще превысокую гору, разноцветные скалы и обрывы, покрытые зеленью высочайшие чинары, дикий виноград, плющ, все в полной зелени, барбарис - все это в осенннее время дышало югом, дышало Грузией. <..> этот край действительно чудный по природе своей и только недостает в нем жителей, которые умели бы наслаждаться и пользоваться краем» ${ }^{43}$.

В главе XIII «Грузия в 1838 году» декабрист А.Е. Розен образно описывает Грузию, Тифлис, особенности его многоязычного населения, нравы и обычаи. Особенно его поразил

\footnotetext{
${ }^{39}$ Гангеблов А.C. Воспоминания // DrevLit.Ru. Библиотека древних рукописей [Электронный pecypc]. URL: http://drevlit.ru/docs/kavkaz/XIX/1820-1840/Gangeblov A S/text1.php (дата обращения: 24.12.2020).

${ }^{40}$ Восстание декабристов: мат-лы. М., 1984. T. XVIII. С. 27.

${ }^{41}$ Розен А.Е. Записки декабриста. Иркутск, 1984. С. 329.

42 Там же. С. 337.

${ }^{43}$ Там же. С. 341.
} 
многоликий Тифлис, ставший центром имперской администрации: «...В Тифлисе все предметы и лица имели особенный не европейской отпечаток; дома с плоскими крышами, армяне с навьюченными верблюдами, грузины с арбами, женщины, покрытые чадрами, ослы с вязанками дров, кони с кожаными мехами на спине, налитыми водою или кахетинским вином» ${ }^{44}$. Отметил А.Е. Розен и особенности характера жителей Тифлиса: «Презанимательно было слушать о воинских подвигах; кавказцы почти все мастерски и красноречиво рассказывают: красота природы, беспристанная опасность, презрение смерти...». Им присущи «ловкость выражения» и «охота высказываться хоть редко, но зато метко» ${ }^{45}$.

Как человек деятельный и активный А.Е. Розен подметил, что «население туземное живет для себя в неге и в праздности», не любит выполнять работу, поэтому русские военные или грузины, состоящие на русской военной службе, вынуждены во всем опираться на солдат и приказывать им заниматься физическим трудом ${ }^{46}$. А.Е. Розен затронул эту тему, т.к. во время посещения Кавказа в 1837 г. императором Николаем I произошел экстраординарный случай - арест командира Эриванского карабинерного полка кн. А.Л. Дадиани, который якобы использовал солдат для исполнения неслужебных обязанностей. Он был сослан в Вятку. Дело осложнялось еще тем, что далее последовала отставка командующего Особым Кавказским корпусом барона Г.В. Розена, т.к. кн. Дадиани был его зятем, а также начальника Генерального штаба В.Д. Вольховского, родственника самого А.Е. Розена. Как Г.В. Розен, так и В.Д. Вольховский заслужили на Кавказе уважение своей деятельностью, и поэтому решение Николая I не разделяла значительная часть офицеров корпуса и местного общества. Такие решения А.Е. Розен связывает с исходящими как из Петербурга, так и с Кавказа доносами чиновников, которые были недовольны излишне мягкой политикой Г.В. Розена и В.Д.Вольховского по отношению к местному населению и служившим на Кавказе декабристам. Таков, по сути дела, подтекст этого сюжета «Записок декабриста».

А.Е. Розен высказывает негативное отношение к миссии сенатора П.В. Гана, предложившего ускорить введение общероссийских порядков на Кавказе. Декабрист прямо заявил, что «такие гости в отдаленной стране от центра правительства, вдали от высшей власти невольно становились особым центром» принимать доносы ${ }^{47}$. Показательно также высказывание будущего наместника Кавказа (с 1845 г.) М.С. Воронцова, что после А.П. Ермолова самым деятельным командующим на Кавказе был Г.В. Розен. Декабрист А.Е. Розен явно чурался бюрократов, чиновников, не желавших учитывать местные особенности, нравы, историю и культуру: «Все это дело имело бы другой оборот, если бы государь во время путешествия и обозрения края имел при себе одного по очереди из местных начальников, которые могли бы объяснить многие особенности страны, и жителей, и быта» ${ }^{48}$.

О мировоззрении А.Е. Розена как представителя «культурного типа декабриста» во многом говорит характеристика, данная им своему родственнику Владимиру Дмитриевичу Вольховскому. Она, может быть, и несколько субъективно окрашена, но, с другой стороны, вполне объяснима ${ }^{49}$. Друг декабристов Вольховский много сделал для облегчения их незавидной участи на Кавказе, показав себя с самой лучшей стороны. В.Д. Вольховский, начальник штаба Отдельного Кавказского корпуса, был не только прекрасным военным стратегом, которого ждала прекрасная военная карьера. Он был лучшим лицеистом первого выпуска (1817 г.), всесторонне образованным человеком, которого глубоко тревожили судьбы родины, поэтому вступил в тайное политическое общество, что впоследствии и отразилось отношением к нему со стороны императора, его бюрократии, завистников. Одним из них был И.Ф. Паскевич, будущий главнокомандующий на Кавказе. В.Д. Вольхов-

\footnotetext{
${ }^{44}$ Розен А.Е. Записки декабриста... С. 344.

45 Там же. С. 349.

${ }^{46}$ Там же. С. 354.

47 Там же. С. 352.

${ }^{48}$ Там же. С. 355.

${ }^{49}$ Там же. С. 359-363.
} 
ского отличали широта души, стремление оказать помощь нуждающимся. Он был фанатиком дела в хорошем смысле этого слова, принял активное участие в военных экспедициях 1819 г. в Хиву, 1824 г. в Бухару, имевших большое значение для открытия Средней Азии для России. Позже В.Д. Вольховский освобождал Грузию, Армению.

А.Е. Розен принадлежал к той же категории декабристов, которые отличались своим позитивным восприятием Кавказа, уважали его историю, культуру, традиции и обычаи, видели необходимость модернизации на Кавказе, учитывая его особенности. Хотя в «Записках декабриста» А.Е. Розена присутствует некий скепсис: «История повествует, что со времени похода аргонавтов до переселения народов и в продолжение крестовых походов различные племена проходили чрез Кавказские горы; остатки многих племен этих оставались тут, сохранили свой первообраз, свой язык, но не оставили ничего примечательного» ${ }^{50}$. Нет, Кавказ, конечно, поражал декабристов красотой, древней историей, нравами и обычаями «диких горцев», многоликостью этносов и религий, и оказал значительное влияние на их мировосприятие, к чему эти деятельные и разносторонние люди были готовы. Это придало им новую энергию и подтвердило, что их «труд не пропал» даром.

K кругу «культурного типа» декабристов принадлежал Николай Иванович Лорер (1794-1873), родом из херсонских дворян, майор Вятского пехотного полка. Член Северного и Южного тайных обществ, он был осужден на 12 лет каторги, сослан в Читинский острог, затем в Петровский Завод. По ходатайству племянницы, фрейлины императрицы А.О. Смирновой-Россет, переправлен в Курган Тобольской губернии, затем солдатом на Кавказ в 1837 г. Принимал активное участие в боях с горцами в Причерноморье. По состоянию здоровья получил отставку в чине прапорщика в феврале 1842 г., и остаток жизни прожил в Херсонской губернии. Уже в пожилом возрасте (70 лет) написал свои мемуары - «Записки моего времени. Воспоминание о прошлом», в которых отражены жизнь и деятельность декабристов в ссылке, затем военная служба на Кавказе. Через «Воспоминание о прошлом» чередой проходят декабристы, те люди, с которыми ему пришлось столкнуться в жизни. Приведем несколько сюжетов, которые свидетельствуют о мировоззрении декабриста Н.И. Лорера. Оставаясь верным идеям декабризма, вспоминая о Тобольске, где он общался с друзьями-декабристами А.И. Одоевским и А.И. Черкасовым, Н.И. Лорер писал о том времени: «Не ребячество, а любовь к отечеству и стремление на развалинах деспотизма, самого самодурного, самого пагубного для общества, построить благо России! Но время еще не настало, Русь наша была еще слишком далека от сознания необходимости реформы в верху и в основании. <..> сколько прекрасных людей бесчеловечная Следственная комиссия наша погубила?» ${ }^{51}$

Будучи уже на Кавказе и участвуя в боях с горцами, Н.И. Лорер был возмущен тем зверством, с которым генерал Г.Х. Засс расправлялся с горцами, отрезая им головы и выставляя напоказ в Прочном Окопе. Он был сторонником действий тех военных чинов, которые искали иные, мирные, культурные пути разрешения проблем с горцами: «...И я невольно сравнил его с анапским комендантом Ротом, который придерживается совершенно противной системы и старается привязать к себе горцев ласковым, человеческим обращением и соблазняет их выгодами и барышами торговли как вернейшим средством указать дикарям выгоду сближения с образованным народом - русскими» ${ }^{52}$. И здесь проявляется идеология цивилизаторской миссии в отношении «дикарей», «хищников», но все-таки это не грубое отношение к другой культуре, что было характерно для определенной группы декабристов. На страницах «Записок моего времени» много эпизодов, в которых автор преклоняется перед величественной природой Кавказа, а также острой критики в адрес действий кавказских чиновников, не желающих учитывать местную культуру и традиции.

Видное место среди декабристов-кавказоведов принадлежит Александру Петровичу Беляеву (1803-1887). Он был мичманом Гвардейского экипажа, одним из основателей

\footnotetext{
${ }^{50}$ Розен А.Е. Записки декабриста... С. 357.

51 Лорер Н.И. Записки декабриста. Иркутск, 1984. С. 181.

${ }^{52}$ Там же. С. 259.
} 
тайного Общества Гвардейского экипажа в 1824 г. Участвовал в восстании на Сенатской площади, был приговорен к лишению чинов и дворянства. Сначала отбывал наказание в Сибири, а с 1840 г. отправлен на Кавказ, участвовал в Кавказской войне. А.П. Беляев в конце своей жизни написал «Воспоминания декабриста о пережитом и перечувствовенном» в двух частях (1882-1887), отражающие не только трудную, но и колоритную жизнь человека, не «отказавшегося от свободы слова и мысли в границах закона нравственного и Божественного». После 21 года ссылки он остался верен идеалам декабризма, хотя многое в его взглядах на историю декабризма изменилось, что нашло отражение в мемуарах.

Он писал, что «история составляется из добродетелей, пороков и заблуждений людей, из их общественной и частной жизни, их взаимных отношений, из их нравов, обычаев, образа жизни» ${ }^{53}$. Всю эту гамму взаимоотношений декабрист А.П. Беляев пронес через свою душу и ум и вполне отразил в своих «Воспоминаниях». Он так же, как Е.Е. Лачинов, стал в заточении, ссылке философом поневоле. Свобода, согласно его христианским убеждениям, не может быть выше нравственного долга. Долг можно посвятить в жертву Отечеству, жертвуя собой, но не другими: «Тот подвиг высок, святой, когда он жертвует своей жизнью, а не чужой, не мятежами, не возмущением всех страстей, не разнузданностью всех дурных инстинктов. Такая свобода усиливает пороки и преступления» ${ }^{54}$.

Так, А.П. Беляев противопоставлял православие, христианскую нравственность буржуазной свободе, вседозволенности. С такими же принципами он относился к народам Кавказа. Он оставил красочные, поразительные по тонкости описания быта и нравов грузин, почувствовал всей душой, какую древнюю и полную опасностей историю прошел этот гордый народ: «Грузинский народ занимает то место в нашем старом свете, где, как в ворота проходили бесчисленные народы из Азии в Европу. Что должен был испытать в разное время этот народ, чтобы удержаться в своей прекрасной стране?» Грузинский народ воспитал в себе те качества, которые его отличают: «Опасности и битвы должны были питать любовь к родине, святыне, воспитывать воинскую доблесть и мужество. Этот народ доселе сохранил во всей чистоте, среди всех превратностей и мученических страданий свою Православную апостольскую церковь...» ${ }^{55}$ В этих словах звучит преклонение перед Грузией, ее историей, культурой. А.П. Беляеву чуждо высокомерие к народам Кавказа, которых чиновники называли «хищниками» и «дикарями».

Декабрист А.П. Беляев отметил особый колорит Тифлиса: «В Тифлисе же еще возбуждал особенный интерес сам город со своей восточной физиономией, с пестрым населением всех возможных восточных народов» ${ }^{56}$. Это было описание Тифлиса со своим многокрасочным миром ремесленников, торговцев, которое сразу бросалось в глаза. А.П. Беляев описал Тифлис 1840 года, и он не мог сравнить его с Тифлисом 1817 года, когда там впервые появился Е.Е. Лачинов, отправлявшийся в свите А.П. Ермолова в Персию. Вторично Е.Е. Лачинов побывал в Тифлисе в 1827 г. и видел, какие разительные перемены в нем произошли. Европеизация затронула и этот восточный город, ставший центром Закавказья.

Впоследствии М.А. Полиевктов своими кавказоведческими трудами доказал «транзитную роль Кавказа» в общении Европы и Азии ${ }^{57}$. Дискурс «восточно-кавказского вопроса» в значительной степени питала христианская идея нравственного долга России как «третьего Рима» нести Крест на Восток, Кавказ. В таком духе воспринимали «восточно-кавказский вопрос» религиозные мыслители Ф.М. Достоевский, Н.Я. Данилевский и идеологи славянофилов, а позднее «евразийцы».

\footnotetext{
${ }^{53}$ Беляев А.П. Воспоминания декабриста о пережитом и перечувствованном // DrevLit.Ru. Библиотека древних рукописей [Электронный ресурс]. URL: http://drevlit.ru/docs/kavkaz/XIX/1840-1860/Beljaev A P/text1.php (дата обращения: 25.12.2020).

54 Там же.

55 Там же.

56 Там же.

${ }^{57}$ Максимчик А.Н. Рукопись проф. М.А. Полиевктова «Россия и Кавказ, как проблема истории русской внешней политики» (1924) // Кавказский Сборник. 2014. № 8 (40). С. 260-277.
} 
Можно утверждать, что Е.Е. Лачинов, А.С. Гангеблов, А.Е. Розен, А.П. Беляев представляют собой определенный культурный тип «декабристов-кавказоведов», которых объединяет высокая христианская православная нравственность, исходящая из нее свобода мысли и слова, активная деятельность, жертвенность во имя Отечества, уважение традиций и обычаев тех народов, которые волей судьбы оказались в Российской империи. Они лишены великодержавного шовинизма, цинизма по отношению к местному населению, чем так отличались в своем большинстве колониальные чиновничество и бюрократия. То нравственное кредо, которое несли декабристы на Кавказе, снискало уважение к ним со стороны кавказского общества, сблизило их с лучшими представителями той части кавказской элиты, которая через русскую культуру усваивала лучшие достижения европейского Просвещения.

В исследовании В.С. Шадури «Декабристская литература и грузинская общественность» и других трудах этого видного грузинского ученого полно представлены факты интенсивного сотрудничества декабристов с прогрессивной частью грузинского общества. Их сближали просветительские идеи преобразования общества на разумных началах, уважения свобод личности, сохранения традиций этносов, прошедших испытания «колесом истории». В этом отношении декабристов выделенного культурного типа объединяло толерантное отношение к культуре народов Кавказа, понимание ее самобытности, необходимости отношения к кавказскому миру как к сложному, многомерному и противоречивому, требующему культурно-цивилизаторского подхода. Они отвергали перевороты, революцию как средство достижения цели, были сторонниками постепенных преобразований, прежде всего в экономической и нравственной сфере.

Исследование темы «культурный тип декабриста» выдвигает ряд проблем мировоззренческого плана, психоидеологического анализа облика подобного типа декабристов, отличающихся в ментальном, нравственном отношении в подходах к другому типу культуры, цивилизации. Они обнаруживают способность понимания иного культурного образа жизни, истории, толерантного отношения к традициям и обычаям, адаптации к ним, а также усвоения иных традиций, что позволяет им развивать проявления лучших качеств своей культуры.

Представители «культурного типа декабристов» были глубокими приверженцами христианской морали, жертвовали собой ради Отечества. Но не позволяли себе ради своих целей жертвовать другими. В этом их отличие от адептов «разумного эгоизма», представителей просветительской идеологии буржуазного толка. Можно согласиться с В.М. Боковой, что тема «декабристы и религия» еще далеко не разработана, как и не предложена новая концепция декабризма. Ее создание позволило бы полнее представить нравственное кредо декабристов ${ }^{58}$.

К такому типу декабристов, условно выделяемых как «культурный тип», можно отнести Е.Е. Лачинова, А.С. Гангеблова, А.Е. Розена, Н.А. Лорера, А.П. Беляева, краткий анализ культурно-нравственного облика которых был сделан в этой статье через восприятие ими особенностей истории и культуры Кавказа.

\section{Лumepamypa}

Андреева T.В. Тайные общества в России в первой трети XIX в.: правительственная политика и общественная мысль. СПб.: Лики России, 2009. 912 с.

Багратион-Мухранели И.Л. Другая жизнь и берег дальний. М.: Изд-во Батаевой, 2014. 460 c.

Балахнина В.Ю. Декабристы как социокультурный тип человека. Саарбрюккен: LAP LAMBERT Academic Publishing, 2011. 204 c.

\footnotetext{
${ }^{58}$ Бокова B.M. Декабристы и их время // История России. Мультимедиа-учебник [Электронный ресурс]. URL: http://www.history.ru/content/view/892/87/ (дата обращения: 25.12.2020).
} 
Барамия Л. Декабрист А. Гангеблов (Гангеблидзе). Тбилиси: Архивное упр. МВД ГрузССР, 1951. 83 с.

Барамия Л. Декабристы в Грузии. Тбилиси: Госиздат, 1955. 204 с.

Беляев А.П. Воспоминания декабриста о пережитом и перечувствованном // DrevLit.Ru. Библиотека древних рукописей [Электронный ресурс]. URL: http://drevlit.ru/docs/kavkaz/XIX/ 1840-1860/Beljaev A P/text1.php (дата обращения: 25.12.2020).

Бокова В.М. Декабристы и их время // История России. Мультимедиа-учебник [Электронный ресурс]. URL: http://www.history.ru/content/view/892/87/ (дата обращения: 25.12.2020).

Ватейшвили Дж.Л. Декабристы на Кавказе. Дело Сухорукова // Вопросы новой истории Грузии. Тбилиси: Мецниереба, 1971. С. 223-258.

Вейденбаум Е.Г. Декабристы на Кавказе в 1829 году // Русская старина. 1903. Т. 34. C. 481-502.

Вольф С.П. Представления о пространстве и времени в картине мира декабристов: автореф. дис. ... канд. ист. наук. Омск, 2012. 23 с.

Восстание декабристов: мат-лы / под ред. М.В. Нечкиной. М.: Наука, 1984. T. XVIII. 368 с.

Гангеблов A.C. Воспоминания // DrevLit.Ru. Библиотека древних рукописей [Электронный ресурс]. URL: http://drevlit.ru/docs/kavkaz/XIX/1820-1840/Gangeblov A S/ text1.php (дата обращения: 24.12.2020).

Гачев Г.Д. Национальные образы мира. Кавказ. М.: Издательский сервис, 2002. 416 с.

Гвинчидзе О.Ш. Из истории общественного движения в России конца XVIII в. (Евграф и Петр Грузиновы): автореф. дис. ... канд. ист. наук. Тбилиси, 1958. 27 с.

Гозалишвили Г.К. Заговор 1832 года. Тбилиси: Мерани, 1970. Т. 2. 655 с.

Гордин Я.А. Мятеж реформаторов.14 декабря 1825 г. Л.: Лениздат, 1985. 385 с.

Гордин Я.А. Кавказская война (1722-1864) как диалог культур. СПб.: ГУП, 2018. 28 с.

Гордин Я.А. Кавказская Атлантида. 300 лет войны // Мир книг [Электронный ресурс]. URL: https://mir-knig.com/read 222249-1 (дата обращения: 22.12.2020).

Гоцадзе М.К. Соломон Додашвили. Тбилиси: Госиздат, 1955. 272 с.

Гуревич А.Я. От истории ментальности к историческому синтезу // Споры о человеке. Дискуссии о настоящем и будущем исторической научной французской школы «Анналы». М.: Наука, 1993. С. 20-27.

Декабристы об Армении и Закавказье: сб. док-тов и мат-лов / сост. и ред. М.Г. Нерсисян. Ереван: Изд-во АН АрмССР, 1985. Ч. 1. 407 с.

Дзидзария Г.А. Декабристы в Абхазии. Сухуми: Алашара, 1970. 117 с.

Дударев Д.С., Дударев С.Л. Жизнь северокавказских горцев в мемуарах декабристов // Вопросы истории. 2015. № 1. С. 79-89.

Жордания О.К. Декабрист А.М. Муравьев и его записки «Мой журнал». Тбилиси: Мецниереба, 1990. 179 с.

Ибрагимбейли X.M. Россия и Азербайджан в первой трети XIX века: (из военно-политической истории). М.: Наука, 1969. 286 с.

Канделаки Д.Г. Дневниковые записки декабриста Е.Е. Лачинова // Русский язык и литература в пространстве мировой культуры: мат-лы ХІІІ Конгресса МАПРЯЛ. СПб.: МАПРЯЛ, 2015. С. 247-251.

Карпов Ю.Ю. Взгляд на горцев. Взгляд с гор: мировоззренческие аспекты культуры и социальный опыт горцев Дагестана. СПб.: Петербургское Востоковедение, 2007. 656 с.

Киянская О.И. Декабристы. М.: Молодая гвардия, 2015. 383 с.

Косвен М.О. Декабристы-кавказоведы // Косвен М.О. Этнография и история Кавказа: иссл. и мат-лы. М.: Изд-во восточной литературы, 1961. С. 155-184.

Лапин В.В. История Кавказской войны. Пособие к лекционному курсу. СПб.: НесторИстория, 2003. 82 с.

Лачинов Е.Е. Отрывок из «Исповеди» // Кавказский Сборник. 1876. Т. 1. С. 123-196. 
Лорер Н.И. Записки декабриста. Иркутск: Восточно-Сибирское книжное изд-во, 1984. 416 c.

Лотман Ю.М. Беседы о русской культуре. Быт и нравы русского дворянства (XVIII начало ХІХ века). СПб.: Искусство-СПБ, 2001. 415 с.

Лотман Ю.М. Декабрист в повседневной жизни // Литературное наследство декабристов. Л.: Наука, 1975. С. 25-74.

Максимчик А.Н. Рукопись проф. М.А. Полиевктова «Россия и Кавказ, как проблема истории русской внешней политики» (1924) // Кавказский Сборник. 2014. № 8 (40). С. 260-277.

Мирзоян Е.В. Сибирская и кавказская ссылки декабристов в 1825-1856 гг.: Опыт сравнительного исследования: автореф. дис. ... канд. ист. наук. Новосибирск, 2003. 30 с.

Нерсисян М.Г. Декабрист Е. Лачинов и его записки об Армении // Из истории русскоармянских отношений. Ереван: АН АрмССР, 1956. Кн. 1. С. 179-220.

Орлик О.В. Декабристы и внешняя политика России. М.: Наука, 1984. 285 с.

Парсамян В.А. Декабристы в Армении. Ереван: Айастан, 1975. 103 с.

Полиевктов М.А. Записки декабриста А.М. Муравьева в библиотеке Тбилисского университета // Труды Тифлисского государственного университета. 1936. Т. 1. С. 348-354.

Розен А.Е. Записки декабриста. Иркутск: Восточно-Сибирское книжное изд-во, 1984. $480 \mathrm{c}$.

Сакварелидзе Р.Д. К вопросу о существовании «Кавказского тайного общества» // История СССР. 1959. № 5. С. 126-127.

Седова М.И. Политическая культура декабристов в контексте российской истории XIX века: автореф. дис. ... д-ра ист. наук. Краснодар, 2006. 38 с.

Серова М.И. Влияние декабристов на развитие культуры Черномории // Культурная жизнь юга России. 2014. № 1 (52). С. 89-92.

Сохвадзе Б.К. Декабристское движение и грузинская общественность. Тбилиси: Изд-во Тбилисского ун-та, 1976. 193 с.

Сулаберидзе Ю.С. Декабрист Е.Е. Лачинов: размышления о прожитом. Саарбрюккен: LAP LAMBERT Academic Publishing, 2016. 108 c.

Хачапуридзе Г.В. Дворянское движение в Грузии в 30-х годах XIX столетия // Вопросы истории. 1950. № 7. С. 45-60.

Хачапуридзе Г.В. К истории Грузии первой половины XIX века. Тбилиси: Заря Востока, 1950. 562 c.

Шадури В.С. Декабристская литература и грузинская общественность. Тбилиси: Заря Востока, 1958. 578 с.

Шадури В.С. Покровитель сосланных на Кавказ декабристов и опальных литераторов: неизвестные материалы о лицейском друге Пушкина В.Д. Вольховском. Тбилиси: Сабчота Сакартвело, 1979. 50 с.

Эрлих С.Е. Война мифов: память о декабристах на рубеже тысячелетий. СПб.: НесторИстория, 2016. 550 с.

Эсадзе С.С. Декабристы в Закавказье. Тбилиси: [б.и.], 1925. 108 с.

\section{References}

Andreeva, T.V. (2009). Tainye obshchestva $v$ Rossii v pervoi treti XIX v.: pravitelstvennaya politika i obshchestvennaya mysl [Secret societies in Russia in the first third of the $19^{\text {th }}$ century: government policy and public thought]. St. Petersburg, Liki Rosii. 912 p.

Bagration-Mukhraneli, I.L. (2014). Drugaya zhizn i bereg dalniy [Another life and a distant shore]. Moscow, Izd-vo Bataevoi. 460 p.

Balakhnina, V.Yu. (2011). Dekabristy kak sotsiokulturnyy tip cheloveka [Decembrists as a socio-cultural type of person]. Saarbrücken, LAP LAMBERT Academic Publishing. 204 p.

Baramiya, L. (1951). Dekabrist A. Gangeblov (Gangeblidze) [Decembrist A. Gangeblov (Gangeblidze)]. Tbilisi, Arkhivnoe upr. MVD GruzSSR. 83 p.

Baramiya, L. (1955). Dekabristy v Gruzii [Decembrists in Georgia]. Tbilisi, Gosizdat. 204 p. 
Belyaev, A.P. Vospominaniya dekabrista o perezhitom i perechuvstvovannom [Decembrist's memories of the experienced and re-sensed]. In DrevLit.Ru. Biblioteka drevnikh rukopisei [DrevLit.Ru. Library of ancient manuscripts]. Available at: URL: http://drevlit.ru/docs/kavkaz/ XIX/1840-1860/Beljaev A P/text1.php (date of access 25.12.2020).

Bokova, V.M. Dekabristy i ikh vremya [Decembrists and their time]. In Istoriya Rossii. Multimedia-uchebnik [Russian history. Multimedia tutorial]. Available at: URL: http:// www.history.ru/content/view/892/87/ (date of access 25.12.2020).

Dudarev, D.S., Dudarev, S.L. (2015). Zhizn severokavkazskikh gortsev v memuarakh dekabristov [The life of the North Caucasian highlanders in the memoirs of the Decembrists]. In Voprosy istorii. No. 1, pp. 79-89.

Dzidzariya, G.A. (1970). Dekabristy v Abkhazii [Decembrists in Abkhazia]. Sukhumi, Alashara. 117 p.

Erlikh, S.E. (2016). Voina mifov: pamyat o dekabristakh na rubezhe tysyacheletiy. [The war of myths: The memory of the Decembrists at the turn of the milennium]. St. Petersburg, NestorIstoriya. $550 \mathrm{p}$.

Esadze, S.S. (1925). Dekabristy v Zakavkazie [Decembrists in Transcaucasia]. Tbilisi. 108 p.

Gachev, G.D. (2002). Natsionalnye obrazy mira. Kavkaz [National images of the world. Caucasus]. Moscow, Izdatelskiy servis. 412 p.

Gangebelov, A.S. Vospominaniya [Memories]. In DrevLit.Ru. Biblioteka drevnikh rukopisei [DrevLit.Ru. Library of ancient manuscripts]. Available at: URL: http://drevlit.ru/docs/kavkaz/ XIX/1820-1840/Gangeblov A S/text1.php (date of access 25.12.2020).

Gordin, Ya.A. (1985). Myatezh reformatorov. 14 dekabrya $1825 \mathrm{~g}$. [The rebellion of the reformers. December 14,1825]. Leningrad, Lenizdat. 385 p.

Gordin, Ya.A. (2018). Kavkazskaya voina (1722-1864) kak dialog kultur [The Caucasian War (1722-1864) as a dialogue of cultures]. St. Petersburg, GUP. 28 p.

Gordin, Ya.A. Kavkazskaya Atlantida [Caucasus Atlantis]. In Mir knig [World of books]. Available at: URL: https://mir-knig.com/read 222249-1 (date of access 25.12.2020).

Gotsadze, M.K. (1955). Solomon Dodashvili. Tbilisi, Gosizdat. 272 p.

Gozalishvili, G.K. (1970). Zagovor 1832 goda [Conspiracy of 1832]. Tbilisi, Merani, vol. 2. $655 \mathrm{p}$.

Gurevich, A.Ya. (1993). Ot istorii mentalnosti k istoricheskomu sintezu [From the history of mentality to historical synthesis]. In Spory o cheloveke. Diskussii o nastoyashchem i budushchem istoricheskoi nauchnoi frantsuzskoy shkoly “Annaly”. Moscow, pp. 20-27.

Gvinchidze, O.Sh. (1958). Iz istorii obshchestvennogo dvizheniya v Rossii kontsa XVIII v. (Evgraf i Petr Gruzinovy) [From the history of social movement in Russia at the end of the 18th century. (Evgraf and Petr Gruzinov’s)], Cand. hist. sci. diss. abstract. Tbilisi. 27 p.

Ibragimbeili, Kh.M. (1969). Rossiya i Azerbaidzhan v pervoi treti XIX veka: (iz voennopoliticheskoi istorii) [Russia and Azerbaijan in the first third of the $19^{\text {th }}$ century century: (from military-political history)]. Moscow, Nauka. 286 p.

Kandelaki, D.G. (2015). Dnevnikovye zapiski dekabrista E.E. Lachinova [Diary notes of the Decembrist E.E. Lachinov]. In Russkiy yazyk i literatura v prostranstve mirovoy kultury. Materialy XIII Kongressa MAPRYAL. St. Peterburg, pp. 247-251.

Karpov, Yu.Yu. (2007). Vzglyad na gortsev. Vzglyad s gor: mirivozzrencheskie aspekty kultury i sotsialnyy opyt gortsev Dagestana [A look at the highlanders. A view from the mountains: the worldview aspect of culture and the social experience of Dagestan]. St. Petersburg, Peterburgskoe Vostokovedenie. 656 p.

Khachapuridze, G.V. (1950). K istorii Gruzii pervoi poloviny XIX veka [On the history of Georgia in the first half of the $19^{\text {th }}$ century]. Tbilisi, Zarya Vostoka. $562 \mathrm{p}$.

Khachapuridze, G.V. (1950). Dvoryanskoe dvizhenie v Gruzii v 30-kh godakh XIX stoletiya [Noble movement in Georgia in the 30s of the $19^{\text {th }}$ century]. In Voprosy istorii. No. 7, pp. 45-60.

Kiyanskaya, O.I. (2015). Dekabristy [Decembrists]. Moscow, Molodaya gvardiya. 383 p. 
Kosven, M.O. (1961). Dekabristy-kavkazovedy [Decembrists-caucasiologists]. In Kosven M.O. Etnografiya i istoriya Kavkaza: issledovaniya i materialy. Moscow, pp. 155-184.

Lachinov, E.E. (1876). Otryvok iz "Ispovedi" [An excerpt from the "Confession"]. In Kavkazskiy Sbornik. Vol. 1, p. 123-196.

Lapin, V.V. (2003). Istoriya Kavkazskoi voiny. Posobie k lektsionnomu kursu [History of the Caucasian War. A compensation to the lecture course]. St. Petersburg, Nestor-Istoriya. 82 p.

Laurer, N.I. (1984). Zapiski dekabrista [Notes of the Decembrist]. Irkutsk, Vostochno-Sibirskoe knizhnoe izd-vo. 416 c.

Lotman, Yu.M. (1975). Dekabrist v povsednevnoi zhizni [Decembrists in everyday life]. In Literaturnoe nasledstvo dekabristov. Leningrad, Nauka, pp. 25-74.

Lotman, Yu.M. (2001). Besedy o russkoi kulture. Byt i nravy russkogo dvoryanstva (XVIII nachalo XIX veka) [Conversations about Russian culture. Life and customs of the Russian nobility $\left(18^{\text {th }}-\right.$ early $19^{\text {th }}$ century) $]$. St. Petersburg, Iskusstvo-SPB. $415 \mathrm{p}$.

Maksimchik, A.N. (2014). Rukopis prof. M.A. Polievktova "Rossiya i Kavkaz, kak problema istorii russkoi vneshnei politiki" (1924) [The manuscript of prof. M.A. Polievktov "Russia and the Caucasus as a problem in the history of Russian foreign policy” (1924)]. In Kavkazskiy Sbornik. No. 8 (40), pp. 260-277.

Mirzoyan, E.V. (2003). Sibirskaya i kavkazskaya ssylki dekabristov v 1825-1856 gg.: Opyt sravnitelnogo issledovaniya [Siberian and Caucasian exile of the Decembrists in 1825-1856: Experience of a comparative study], Cand. hist. sci. diss. abstract. Novosibirsk. 30 p.

Nechkina, M.V. (Ed.). (1984). Vosstanie dekabristov. Materialy [Decembrists uprising. Materials]. Moscow, Nauka, vol. XVIII. 368 p.

Nersisyan, M.G. (1956). Dekabrist E. Lachinov i ego zapiski ob Armenii [Decembrist E. Lachinov and his notes about Armenia]. In Iz istorii russko-armyanskikh otnosheniy. Yerevan, b. 1, pp. 179-220.

Nersisyan, M.G. (Ed.) (1985). Dekabristy ob Armenii i Zakavkaz'e: sb. dokumentov i materialov [Decembrists about Armenia and Transcaucasia: collection of documents and materials]. Yerevan, Izd-vo AN ArmSSR, vol. 1. 407 p.

Orlik, O.V. (1984). Dekabristy i vneshnyaya politika Rossii [Decembrists and foreign policy of Russia]. Moscow, Nauka. 285 p.

Parsamyan, V.A. (1975). Dekabristy v Armenii [Decembrists in Armenia]. Yerevan, Aiastan. $103 \mathrm{p}$.

Polievktov, M.A. (1936). Zapiski dekabrista A.M. Muravieva v biblioteke Tbilisskogo universiteta [Notes of the Decembrist A.M. Muravyov in the library of the Tbilisi University]. In Trudy Tiflisskogo gosudarstvennogo universiteta. Vol. 1, pp. 348-354.

Rosen, A.E. (1984). Zapiski dekabrista [Notes of the Decembrist]. Irkutsk, Vostochno-Sibirskoe knizhnoe izd-vo. 480 p.

Sakvarelidze, R.D. (1959). K voprosu o sushchestvovanii "Kavkazskogo tainogo obshchestva" [On the question of the existence of the "Caucasian secret society"]. In Istoriya SSSR. No. 5, pp. 126-127.

Sedova, M.I. (2002). Politicheskaya kultura dekabristov v kontekste rossiyskoy istorii XIX veka [The political culture of the decembrists in the context of Russia history of the $19^{\text {th }}$ century], Dr. hist. sci. diss. abstract. Krasnodar. 36 p.

Serova, M.I. (2014). Vliyanie dekabristov na razvitie kultury Chernomorii [The influence of the Decembrists on the development of the culture of the Black Sea region]. In Kulturnaya zhizn yuga Rossii. No. 1 (52), pp. 89-92.

Shaduri, V.S. (1958). Dekabristskaya literatura i gruzinskaya obshchestvennost [Decembrists literature and Georgian public]. Tbilisi, Zarya Vostoka. 578 p.

Shaduri, V.S. (1979). Pokrovitel soslannykh na Kavkaz dekabristov i opalnykh literatorov: neizvestnye materialy o litseiskom druge Pushkina V.D. Volkhovskom [The patron saint of the Decembrists and disgraced writers exiled to the Caucasus: unknown materials about Pushkin's lyceum friend V.D. Volkhovsky]. Tbilisi, Sabchota Sakartvelo. 50 p. 
Sokhvadze, B.K. (1976). Dekabristskoe dvizhenie i gruzinskaya obshchestvennost [The Decembrist movement and the Georgian public]. Tbilisi, Izd-vo Tbilisskogo un-ta. 193 p.

Sulaberidze, Yu.S. (2016). Dekabrist E.E. Lachinov: razmyshleniya o prozhitom [Decembrist E.E. Lachinov: reflections on the past]. Saarbrücken, LAP LAMBERT Academic Publishing. $108 \mathrm{p}$.

Vateishvili, Dzh.L. (1971). Dekabristy na Kavkaze. Delo Sukhorukova [Decembrists in the Caucasus. Sukhorukov case]. In Voprosy novoi istorii Gruzii. Tbilisi, pp. 223-258.

Veidenbaum, E.G. (1903). Dekabristy na Kavkaze v 1829 godu [Decembrists in the Caucasus in 1829]. In Russkaya starina. Vol. 34, pp. 481-502.

Volf, S.P. (2012). Predstavleniya o prostranstve i vremeni v kartine mira dekabristov [Representations of space and time in a picture of the world of decembrists], Cand. hist. sci. diss. abstract. Omsk. 23 p.

Zhordaniya, O.K. (1990). Dekabrist A.M. Muraviev i ego zapiski "Moy zhurnal” [Decembrist A.M. Muravyov and his notes "My Journal”]. Tbilisi, Metsniereba. 179 p.

Статья поступила в редакцию 16.03.2020 г. 